\title{
Effects of Mining Activities on the Release of Heavy Metals (HMs) in a Typical Mountain Headwater Region, the Qinghai-Tibet Plateau in China
}

\author{
Wenhao Wei ${ }^{1}\left(\right.$, Rui Ma ${ }^{2,3}, *$, Ziyong Sun ${ }^{2,3}$, Aiguo Zhou ${ }^{2}$, Jianwei Bu ${ }^{2,3}$, Xiang Long ${ }^{2}$ and \\ Yunde Liu ${ }^{2}$ \\ 1 Geological Survey, China University of Geosciences, Wuhan 430074, China; weiwenhao048@cug.edu.cn \\ 2 School of Environmental Studies, China University of Geosciences, Wuhan 430074, China; \\ ziyong.sun@cug.edu.cn (Z.S.); aiguozhou@cug.edu.cn (A.Z.); jangous@163.com (J.B.); \\ longxiang@cug.edu.cn (X.L.); lydcn84@126.com (Y.L.) \\ 3 Laboratory of Basin Hydrology and Wetland Eco-restoration, China University of Geosciences, \\ Wuhan 430074, China \\ * Correspondence: rma@cug.edu.cn; Tel./Fax: +86-27-8757-1276
}

Received: 11 July 2018; Accepted: 4 September 2018; Published: 12 September 2018

\begin{abstract}
Understanding the heavy metal (HM) contamination in alpine mountain headwaters regions is important to maintaining the ecosystem stability of the basin. A total of 119 water samples and 104 sediment samples were collected along tributaries and the main course of Heihe River. The concentrations of eight heavy metals ( $\mathrm{As}, \mathrm{Cd}, \mathrm{Cr}, \mathrm{Cu}, \mathrm{Mn}, \mathrm{Ni}, \mathrm{Pb}$, and $\mathrm{Zn}$ ) in water and sediment were measured to describe their spatial variability and to assess water quality. To identify the origins and pathways of HMs, anions, cations, and trace elements, as well as $\delta \mathrm{D} / \delta^{18} \mathrm{O}$ stable isotopes in water samples were also measured. The results of water quality assessment suggested that tributaries were affected by local mining activity. Factor analysis in sediments showed that all HMs in sediments were inherited from the parent bedrock. Both natural weathering and mining contribute HMs. Cr and $\mathrm{Ni}$ were homologous with a source from the weathering of basic gabbro and serpentine at Yushigou. Mn appeared to be influenced more by artificial activities such as agriculture and grazing. Depending on the mining technique involved, two pathways for the release of HMs were distinguished in this area. For open-pit mining, mining promoted the release of HMs primarily via enhanced weathering. For underground mining, HMs might have contributed to greater acid mine discharge at high elevations due to the weak weathering processes. As the elevation decreases, precipitation increases, and a series of complex hydrological factor significantly affect leaching and runoff. The study results can be applied to improve water management efficiency.
\end{abstract}

Keywords: heavy metals; mining activity; water quality; headwater region

\section{Introduction}

Heavy metal (HM) contamination in water environments has received considerable attention worldwide due to the toxicity, persistence, abundance, and biomagnification of HMs in the environment and their subsequent accumulation in aquatic habitats [1,2]. HMs in water environments originate from multiple sources, including natural processes such as volcanism, bedrock weathering, erosion and anthropogenic activities, such as industry, agriculture fertilization and drainage, and especially mining, metal smelting and refining [1-4]. Many previous studies have shown that the most critical contributor to HM pollution in river basins is mining activity [1,5]. Understanding the concentration, distribution and the sources of HMs in aquatic environments is essential to provide a scientific reference for the protection of water resources and the control of water pollution. 
Like other alpine mountains around the world (e.g., the Alps and Rocky Mountains and the Tibetan Plateau), the headwaters region of the Heihe River basin, often referred as a "water tower", plays an essential role in maintaining the ecosystem stability of the basin. The surface runoff in upstream headwaters contributes approximately $90 \%$ of the water resources in the midstream and downstream areas [6]. In addition, anthropogenic activities such as the expansion of artificial oases, large-scale agricultural development and overuse of synthetic substances in midstream and downstream areas have increased the dependence of the quantity and quality of water resources on upstream headwater regions $[6,7]$.

The headwaters region of the Heihe River basin has gained considerable attention due to the special geological and metallogenic conditions. With the Western Development Initiative (WDI) launched in 2002, the Chinese government has established 22 mineral exploration plan areas on the Qinghai-Tibet Plateau [8], where the Qilian-Tianjun coal, copper, lead, and zinc planning area is located. A large number of mines have been placed into operation since the 1980s. Unsustainable mineral exploration and mining activity have severely damaged the fragile local ecological environment and compromised the water quality [9]. Additionally, some mines are located near glaciers at high elevations [10]. Therefore, the quality of the meltwater, which is the vital source of water for the river, may be deteriorated by mining activity. This area has increasingly drawn the attention of local and central governments [11]. However, many researchers are concerned with quantifying surface runoff to serve for basin water resource allocation [12-18]. Little attention has been paid to the deterioration of the water quality in response to human activities such as mining.

The present study aimed to investigate the contents of $\mathrm{As}, \mathrm{Cd}, \mathrm{Cr}, \mathrm{Cu}, \mathrm{Ni}, \mathrm{Pb}$, and $\mathrm{Zn}$ in water environments across the headwater region of the Heihe River and to determine their regional variability and their natural or artificial origin. By analyzing the spatial distribution patterns of HM elements in surface water, we identify the sources of the HMs, and evaluate the surface water quality. The results can be applied to improve water management efficiency.

\section{Materials and Methods}

\subsection{Study Area}

The headwaters region of the Heihe River basin is located at the northern margin of the Qinghai-Tibet Plateau in the Qilian Mountains of Qinghai Province at $39^{\circ} 51^{\prime}-38^{\circ} 91^{\prime} \mathrm{N}$ and $98^{\circ} 34^{\prime}-100^{\circ} 11^{\prime} \mathrm{E}$ (Figure 1) with a basin area of $5037.38 \mathrm{~km}^{2}$. The main landform is alpine valleys, and the average elevation ranges from 2583 to $4891 \mathrm{~m}$ above mean sea level (m.s.l). The region has a continental alpine climate with a mean annual air temperature of $1{ }^{\circ} \mathrm{C}$ and mean annual precipitation of $420 \mathrm{~mm}$, which mainly occurs in summer. The length of the Heihe River in the study area is more than $175 \mathrm{~km}$, extending from Tieli Mountain through Bayi Glacier to Huangzang Temple. There is apparent vertical zoning in the vegetation landscape.

\subsubsection{Geology}

The headwaters region of the Heihe River belongs to the northern Qilian orogenic belt, which is rich in ores with various nonferrous metals, ferrous metals and nonmetallic building materials [9]. This belt is an NW-SE-trending oceanic suture belt that lies between the Alashan Block and the Qilian Block. The belt is composed of subduction accretionary complexes, including Neoproterozoic to early Paleozoic ophiolite sequences, high-pressure metamorphic rocks, island arc volcanic rocks and granites, and post-Devonian sedimentary cover sequences $[19,20]$. 


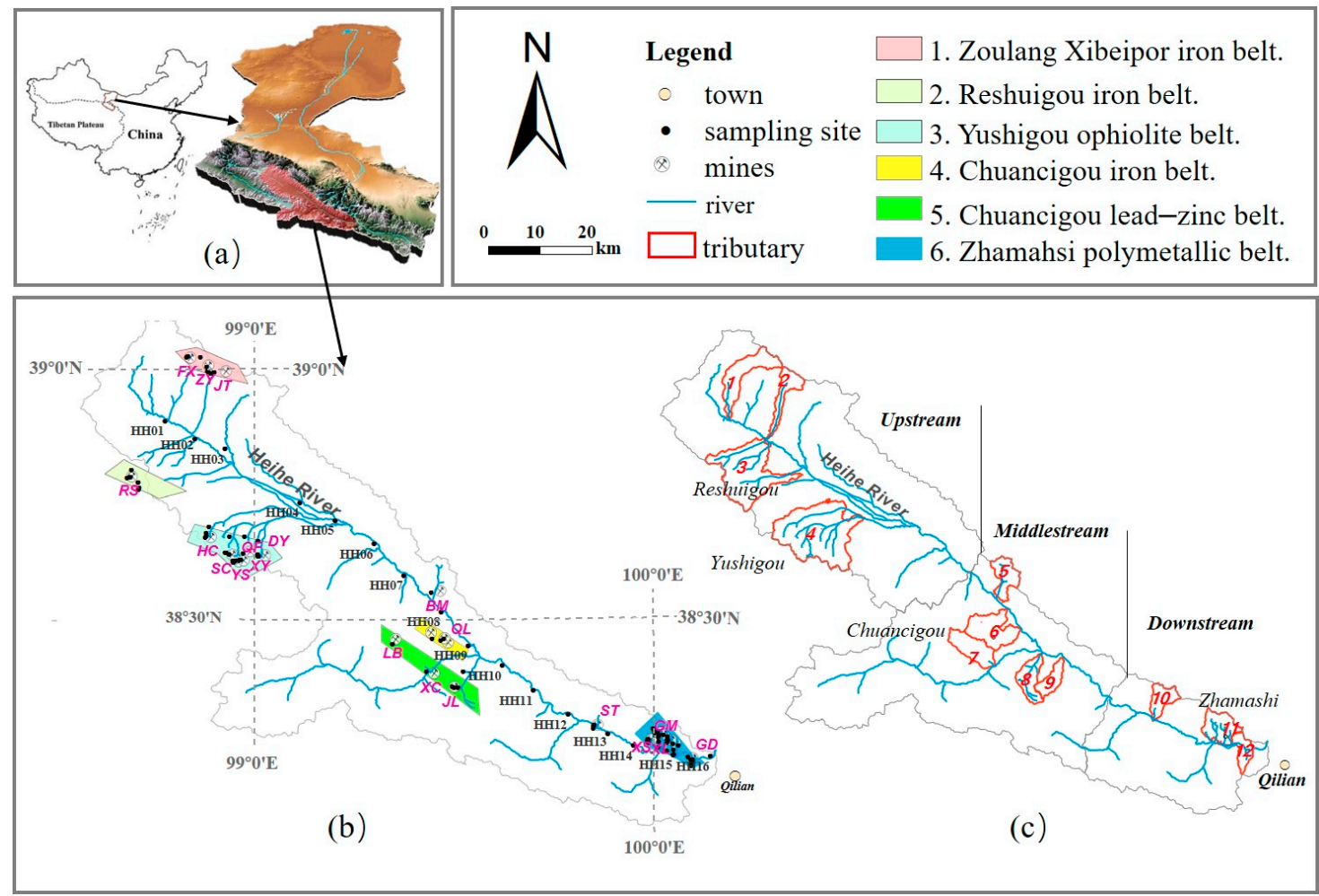

Figure 1. (a) Location of the headwaters region of the Heihe River basin. (b) A map of the sampling sites, including 6 ore concentration areas and 22 mines. The Fengxin (FX); Xiaoshalongzhigou (JT), Xiaoshuigou (ZY); Reshuigou (RS), Shuangchagou (SC), Heicigou (HC), Yushigou (YS), Dongyushigou (DY), and Qifeng (QF) located at the upstream of this study area. The Bianmagou(BM), Xiaoshuigou (QL), Liaobantai (LB), Xinchuan (XC), Daerzhulong (JL) in middle-stream. And Shitougou (ST), Wanyanghe (WY), Xialiugou (XL), Xishanliang (XS), Guomisi (GM), and Xiagou (XG) and Donggou (DG) in downstream area. (c) A map of the investigated tributaries and upstream, middle-stream, and downstream; The number in red within different closed shapes indexes the different tributary. Further detailed information on the tributaries and the mines is shown in Table 1.

\subsubsection{Anthropogenic Activity}

In this typical alpine mountain region, the main anthropogenic activities consist of agricultural, grazing and mining activities. The traditional agriculture in this area has been greatly limited by the cold climate. Town and cropland near the main course of Heihe River were used as sites for the study of agricultural activity, while the grazing activity in this area were usual for wide alpine meadow pastures [21] (shown in Figure S2).

In the study area, the early Paleozoic was the main metallogenic period. The principal deposit combinations are $\mathrm{Cu}-\mathrm{Zn}, \mathrm{Cu}-\mathrm{Pb}-\mathrm{Zn}, \mathrm{Cu}-\mathrm{Ni}$, and $\mathrm{Cr}$. The large-scale mineralizations that formed mineable metals during this period were sulfide deposits. Previous studies showed that the formation of metal sulfide deposits was related to submarine volcanism and subduction orogenic processes [22-24]. There are six ore concentration areas in the different reaches of this basin. There are two iron ore belts in this area, and both of them are metamorphic hydrothermal sedimentary deposits. The Zoulang Xibeipor iron belt is located on the north bank of Heihe River and contains the Xiaoshalongzhigou (JT) and Xiaoshuigou (ZY) deposits. Moreover, the northern Tolle Mountain iron ore belt is located on the south bank of the Heihe River and contains RS and JT iron ore. These ores are produced underground. Both the Yushigou and Chuancigou areas with complete ophiolite sequences $[19,22,23,25]$ are on the south side of the Heihe River. The Yushigou area is a copper-lead-zinc-chromium metallogenic deposit belt, including Shuangchagou (SC), Heicigou (HC), Yushigou (YS), Dongyushigou (DY), and Qifeng (QF) deposits. During the investigation, only open-pit 
mining was found in this area. In the Chuancigou area and Zhamashi area, the copper polymetallic deposits developed in acid island arc volcanic rocks and high-pressure rocks such as blueschist [19], and the Wanyanghe (WY), Xialiugou (XL), Xishanliang (XS), Guomisi (GM), and Xiagou (XG) deposits are located at these areas. These deposits are often coincident with iron and manganese deposits in particular. Underground mining technology has been widely applied in the study area.

\subsection{Water Sample Collection and Analysis}

To assess the water quality of this study area and to identify the source and pathway of the HMs releasing, a total of 119 sets of water samples were collected from and the 22 mines and the main course of Heihe River in August 2013. Figure 1 and Table 1 show all sampling sites and the distribution of mines and tributary catchments, with serval mines for along each tributary. Several mines are located along the upstream tributaries catchment near the glacier. Fifty-eight river water samples were collected in the surface stream around the mines; 10 meltwater samples were collected in several tributaries' headwater streams near the glacier. Seven groundwater samples were collected, including two spring water samples and five samples from drinking water wells. Moreover, six pond water samples were collected around ore slag heap, and 22 samples of mineral leached water were collected from underground mines and opencast dumps, one of which was collected from a tailings pond in the Xinchuan (XC) concentrator. In the main course of the Heihe River, 16 river water samples (HH01-HH16) were collected near the discharge point of those tributaries to determine their contributions to the HMs in the corresponding tributaries (shown in Figure 1).

All water samples were filtered with $0.22 \mu \mathrm{m}$ membranes in the field into polythene bottles that had been thoroughly prewashed with deionized water. During the sampling times, parameters such as $\mathrm{pH}$ and electrical conductivity were measured on site using a portable Hatch Ec and $\mathrm{pH}$ meter (HACH HQ40d, Loveland, CO, USA) with the calibration of $\mathrm{pH} 4, \mathrm{pH} 7$ and $\mathrm{pH} 9$ standards, and alkalinity $\left(\mathrm{HCO}_{3}{ }^{-}\right.$and $\left.\mathrm{CO}_{3}{ }^{2-}\right)$ was determined on the sampling day using the Gran titration method, which determines the equivalent potentiometric point via titration [26] within $12 \mathrm{~h}$ of sampling. Samples for cation and trace element analysis were acidified with ultrapure $\mathrm{HNO}_{3}$ to $\mathrm{pH}=2$ and stored at $4{ }^{\circ} \mathrm{C}$ until being shipped to the laboratory [27] for ion analysis, including the analysis of HMs. To understand the hydrological process using isotope analysis, 99 water samples were collected from different source, including surface stream, pond, underground (well/spring), and mineral leached water. Twenty samples (including 19 mineral leached water samples and one groundwater sample) were abandoned since these samples had high total dissolved solid (TDS) values (greater than $500 \mathrm{mg} / \mathrm{L}$ ).

Anion, cation, minor element, and isotope analyses were all performed in the Laboratory of Basin Hydrology and Wetland Eco-restoration, China University of Geosciences (Wuhan). Anions $\left(\mathrm{SO}_{4}{ }^{2-}\right.$, $\mathrm{NO}_{3}{ }^{-}, \mathrm{Cl}^{-}$, and $\mathrm{F}^{-}$) were measured using ion chromatography (IC; DX-120, Dionex, Sunnyvale, CA, USA), while cations $\left(\mathrm{K}^{+}, \mathrm{Ca}^{2+}, \mathrm{Na}^{+}\right.$, and $\left.\mathrm{Mg}^{2+}\right)$ and certain minor elements $\left(\mathrm{Si}, \mathrm{Fe}\right.$ and $\mathrm{Sr}^{2+}$ ) were determined via inductively coupled plasma atomic emission spectrometry (ICP-AES, iCAP 6300 Duo View ICP-AES spectrometer, Thermo Electron Corporation, Waltham, UK). The wave numbers of $\mathrm{K}^{+}$, $\mathrm{Ca}^{2+}, \mathrm{Na}^{+}, \mathrm{Mg}^{2+} \mathrm{Si}, \mathrm{Fe}$ and $\mathrm{Sr}^{2+}$ were 766.490, 422.673, 589.592, 285.213, 251.661, 259.940 and 407.771, respectively. Ionic balance errors were within $\pm 10 \%$. The isotopic $\delta^{18} \mathrm{O}$ and $\delta \mathrm{D}$ were measured with an ultrahigh-precision isotopic water analyzer (L2130-I, Picarro Inc., Santa Clara, CA, USA). These values were expressed in $\delta$ per milliliter relative to Vienna Standard Mean Ocean Water (V-SMOW), with precisions of $0.025 \%$ and $0.1 \%$, respectively. Trace element analysis was performed on an inductively coupled plasma mass spectrometer (ICP-MS, 7500a, Agilent, Santa Clara, CA, USA) at the State Key Laboratory of Geological Processes and Mineral Resources, China University of Geosciences (Wuhan). ${ }^{115}$ In was used as an internal standard. 


\subsection{Sediments Sample Collection and Analysis}

As sediments contain a historical record of the natural and anthropogenic fluxes of HMs input into the water basin [28], a total of 104 surface sediment samples (0-20 cm in depth) were collected from locations close to sites from which water samples were collected (listed in Table 1 and shown in Figure 2) to analyze the sources of HMs. According to the method described by Bu et al. [10], with a clean plastic dustpan and brush, approximately $1 \mathrm{~kg}$ of fresh sediments was stored in plastic bags. All samples were air-dried at $\sim 20^{\circ} \mathrm{C}$; sorted through a $2 \mathrm{~mm}$ plastic sieve to remove large plant roots, gravel-sized stones, and other debris; ground and homogenized with an agate mortar; and passed through a 200-mesh sieve.

A series of parameters including the concentration of the eight HMs, sediment total organic carbon (TOC), and $\mathrm{pH}$ were determined to better understand the spatial variations and their associations with different metals in the area [29].

Each sample $(0.1 \mathrm{~g})$ of milled soil was collected and placed in a polypropylene vessel and mixed with $2 \mathrm{~mL}$ of concentrated $\mathrm{HNO}_{3}$ and $1 \mathrm{~mL}$ of $\mathrm{HClO}_{4}$. The solution was heated on an open hot plate for approximately $4 \mathrm{~h}$ until white fumes were given off, and then the residue was re-dissolved in a plastic bottle with $2 \mathrm{~mL}$ of $4 \mathrm{~mol} \mathrm{~L}^{-1} \mathrm{HCl}$ and diluted to $10 \mathrm{~mL}$ with deionized water. The concentrations of the eight HMs were measured via inductively coupled plasma mass spectrometry (ICP-MS, 7500a, Agilent, Santa Clara, CA, USA) at the State Key Laboratory of Geological Processes and Mineral Resources, China University of Geosciences. The national standard reference samples GSS-1 and GSR-1 were used for quality control of the analyses. The corresponding relative standard deviation (RSD) values were less than $5 \%$. Total organic carbon in sediment (as a percentage) was measured using a TOC analyzer (VCPH, Shimadzu, Kyoto, Japan).

The $\mathrm{pH}$ of the sediments was measured in 1:2.5 sediment:water. The suspension was left to stands overnight before $\mathrm{pH}$ determination. The $\mathrm{pH}$ was measured using a $\mathrm{pH}$ meter (D-52, Horiba, Kyoto, Japan) with the calibration of $\mathrm{pH} 4, \mathrm{pH} 7$ and $\mathrm{pH} 9$ standards. For electric condutivity (EC) determination, sediment $(5 \mathrm{~g})$ was taken in $50 \mathrm{~mL}$ polypropylene tubes, to which distilled water $(30 \mathrm{~mL})$ was added. The lid was closed tightly, and the tube was shaken for $5 \mathrm{~min}$. Subsequently, EC was measured using an EC meter (D-52, Horiba, Kyoto, Japan).

\subsection{Factor Analysis}

Factor analysis (FA) is a conventional multivariate statistical method that determines the general relationship between measured variables by revealing multidimensional patterns that may be useful for classifying the original data [30-33]. FA is used to explore the possible sources and the hydrogeochemical processes affecting HMs by reducing the dimensionality of the dataset to several influencing factors. In this study, we used SPSS, version 19.0 (SPSS Inc., Chicago, IL, USA), for this analysis. 
Table 1. General information for sampling sites. The detailed information on water and sediment samples is presented. The several tributaries are also divided into different reaches of the headwaters region of the Heihe River basin.

\begin{tabular}{|c|c|c|c|c|c|c|c|c|c|c|c|c|c|c|}
\hline \multirow[b]{2}{*}{ Reaches } & \multirow[b]{2}{*}{ ID $^{a}$} & \multirow[b]{2}{*}{ Mine $^{b}$} & \multirow[b]{2}{*}{ Date } & \multirow[b]{2}{*}{$\begin{array}{l}\text { Mine } \\
\text { Area } \\
\left(\mathrm{km}^{2}\right)\end{array}$} & \multirow[b]{2}{*}{ Ore Type } & \multirow[b]{2}{*}{$\begin{array}{l}\text { Elevation } \\
\text { (m) }\end{array}$} & \multirow[b]{2}{*}{$\begin{array}{c}\text { Mining } \\
\text { Method } \\
\text { (OP/UG) }^{\mathrm{c}}\end{array}$} & \multicolumn{6}{|c|}{ Water Sample Collected from Several Mines } & \multirow[b]{2}{*}{ Sediment } \\
\hline & & & & & & & & Meltwater & $\begin{array}{l}\text { River } \\
\text { Water }\end{array}$ & Groundwater & $\begin{array}{l}\text { Pond } \\
\text { Water }\end{array}$ & $\begin{array}{c}\text { Mineral } \\
\text { Leached } \\
\text { Water }\end{array}$ & Total & \\
\hline \multirow{10}{*}{ Upstream } & 1 & $F X$ & 20/August & 0.087 & Marble & $4280-4582$ & OP & 1 & 1 & & & 3 & 5 & 5 \\
\hline & 2 & JT & 19/August & 1.115 & Polymetallic & $3920-4100$ & UG & & 2 & & 1 & & 3 & 2 \\
\hline & & ZY & 19/August & 0.498 & Iron ore & $4300-4600$ & $\mathrm{OP}$ & & 4 & 1 & & & 5 & 3 \\
\hline & 3 & RS & 18/August & 0.570 & Iron ore & $4190-4290$ & OP & 4 & 5 & & & & 9 & 3 \\
\hline & 4 & $\mathrm{HC}$ & 21/August & 0.105 & Serpentine & $4238-4308$ & OP & & 3 & & & 1 & 4 & 3 \\
\hline & & $X Y$ & 21/August & 0.070 & Serpentine & $4200-4330$ & OP & & 2 & & & & 2 & 1 \\
\hline & & YS & 22/August & 0.056 & Chromite & $4360-4539$ & OP & 5 & & 1 & & & 6 & 1 \\
\hline & & $\mathrm{SC}$ & 23/August & 1.299 & Asbestos & $4362-4630$ & OP & & 3 & & & 2 & 5 & 6 \\
\hline & & $\mathrm{QF}$ & 23/August & 0.313 & Chromite & $4280-4560$ & OP & & 2 & & & 1 & 3 & 2 \\
\hline & & DY & 24/August & 0.034 & Serpentine & $4220-4290$ & OP & & 3 & 1 & & & 4 & 3 \\
\hline \multirow{5}{*}{ Middle-stream } & 5 & $\mathrm{BM}$ & 25/August & 0.107 & Manganese & $3620-3650$ & UG & & 1 & & & & 1 & 5 \\
\hline & 6 & LB & 26/August & 0.523 & Lead-Zinc & $4020-4460$ & $\mathrm{OP} / \mathrm{UG}$ & & 2 & & & & 2 & 1 \\
\hline & 7 & QL & 25/August & 0.520 & Iron ore & $3520-3959$ & UG & & 3 & & & & 3 & 7 \\
\hline & 8 & JL & 15/August & 0.121 & Polymetallic & $3920-4100$ & UG & & 3 & & 1 & 1 & 5 & 4 \\
\hline & 9 & $\mathrm{XC}$ & 26/August & & Ore dressing & & & & & & & 1 & 1 & 3 \\
\hline \multirow{8}{*}{ Down-stream } & 10 & ST & 14/August & 0.160 & Manganese & $3018-3130$ & UG & & 4 & & & 1 & 5 & 3 \\
\hline & 11 & WY & 8/August & 0.189 & Polymetallic & $2790-3150$ & UG & & 6 & 1 & 1 & 1 & 9 & 5 \\
\hline & & $\mathrm{XL}$ & 9/August & 0.117 & Polymetallic & $3084-3460$ & UG & & 2 & 1 & & 1 & 3 & 2 \\
\hline & & XS & 10/August & 0.540 & Polymetallic & $3150-3680$ & $\mathrm{OP} / \mathrm{UG}$ & & 6 & 1 & & 3 & 10 & 10 \\
\hline & & GM & 11/August & 0.134 & Polymetallic & $3000-3530$ & UG & & & 1 & 3 & 4 & 8 & 4 \\
\hline & & $X G$ & 12/August & 0.195 & Polymetallic & $2730-3159$ & UG & & 4 & & & & 4 & 8 \\
\hline & 12 & GD & 13/August & 0.550 & Polymetallic & $3760-4030$ & UG & & 2 & 1 & & 3 & 6 & 5 \\
\hline & & $\mathrm{HH}$ & $27,28 /$ August & & & & & & 16 & & & & 16 & 18 \\
\hline Total & 14 & & & & & 104 & & 10 & 74 & 7 & 6 & 22 & 119 & 104 \\
\hline
\end{tabular}

Space indicates no corresponding information is provided. ${ }^{a}$ The serial number of the tributary catchment investigated along the Heihe River. ${ }^{\mathrm{b}}$ all mine locations in Table 1 have been defined in Section 2.1.2 and Figure 1; HH-main course of the Heihe River. ${ }^{c}$ UG-underground mining; OP-open pit mining. 


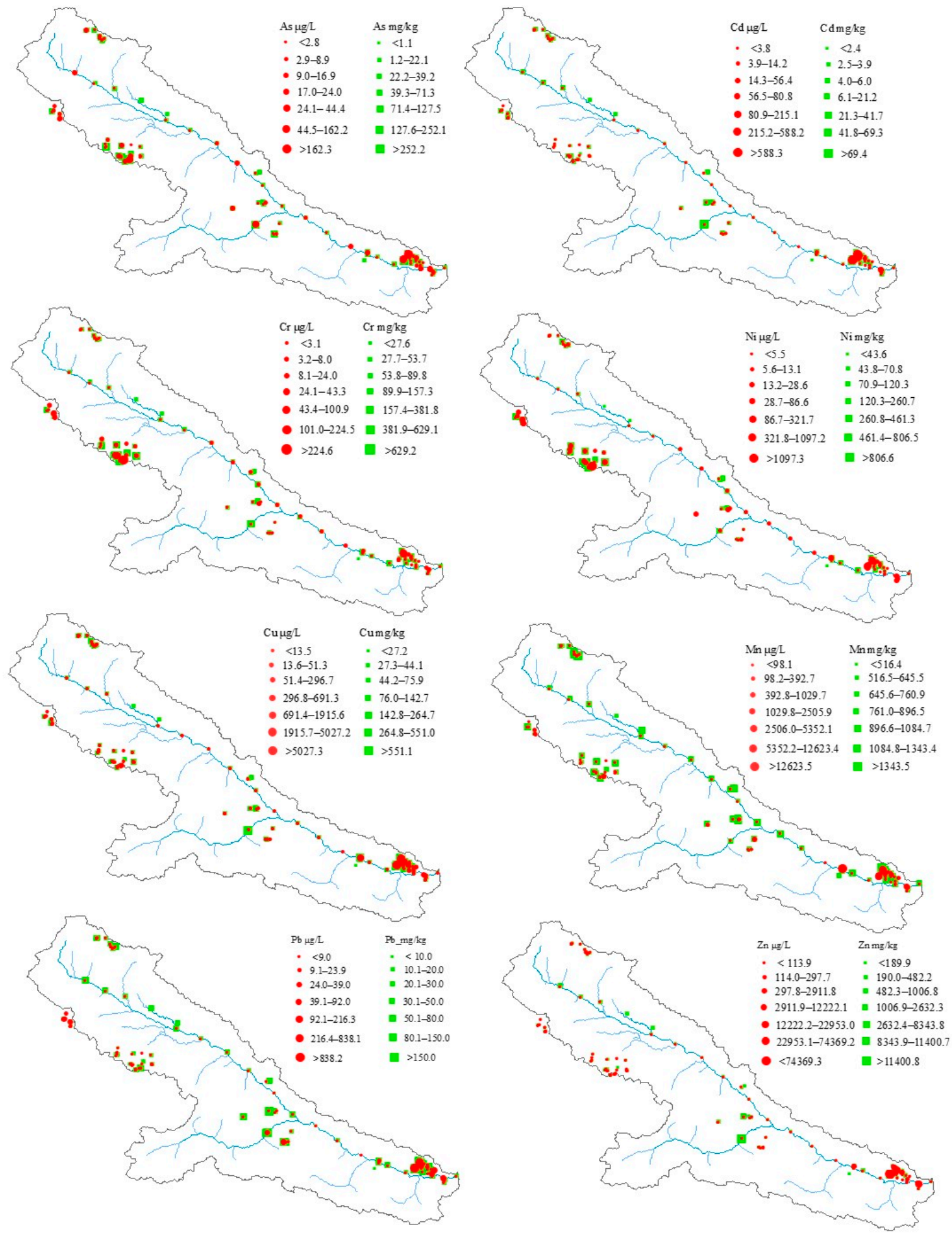

Figure 2. Distributions of heavy metals in surface sediments and waters. Green squares describe levels of HMs in sediment (units: $\mathrm{mg} / \mathrm{kg}$ ), and red circles describe HMs in water (units: $\mu \mathrm{g} / \mathrm{L}$ ). 


\section{Results and Discussion}

\subsection{Water Quality Assessment}

Water contamination by $\mathrm{HMs}$ ( $\mathrm{As}, \mathrm{Mn}, \mathrm{Cr}, \mathrm{Ni}, \mathrm{Cu}, \mathrm{Cd}, \mathrm{Pb}$, and $\mathrm{Zn}$ ) was evaluated by comparing their concentrations with the guidelines for drinking water and surface water established by the China Environment Protect Agency (EPA) in 2002 and 2006 (Table 2). Because the surface water quality in this headwaters region plays an essential role in the supply of water resource, Grade I of Chinese surface water standards (GB 3838-2002) [34] served as the primary guideline value against which to evaluate the $\mathrm{HM}(\mathrm{As}, \mathrm{Cr}, \mathrm{Cu}, \mathrm{Cd}, \mathrm{Pb}$, and $\mathrm{Zn}$ ) contamination. For $\mathrm{Mn}$ and $\mathrm{Ni}$, the guideline values provided by the Chinese drinking water standards (GB 5749-2006) were used [35]. Mineral leached water and pond water were not evaluated, because there was no direct hydraulic connection between these points and the Heihe River, although the samples contain high levels of HMs.

Table 2. Chinese national quality standards for drinking water and surface water quality (units: $\mu \mathrm{g} / \mathrm{L}$ ).

\begin{tabular}{ccccccccc}
\hline Water Standard & As & $\mathbf{M n}$ & $\mathbf{C r}$ & $\mathbf{N i}$ & $\mathbf{C u}$ & $\mathbf{C d}$ & $\mathbf{P b}$ & $\mathbf{Z n}$ \\
\hline Grade I $^{\mathrm{a}}$ & 10 & - & 10 & - & 10 & 1 & 10 & 50 \\
Drinking $^{\mathrm{b}}$ & 10 & 100 & 10 & 20 & 1000 & 5 & 10 & 1000 \\
\hline
\end{tabular}

(-) Indicates no information is provided; ${ }^{a}$ Chinese surface water standards (GB 3838-2002) [34]. Grade I: Clean water from headwater and national conservation area that can be used for domestic purposes after simple disinfection, for recreational purposes and irrigation; ${ }^{b}$ Chinese drinking water standards (GB 5749-2006) [35].

As shown in Table 2, the results of water quality in the headwaters region of the Heihe River, all HMs in the main course were within the corresponding guideline values, indicating that the water quality of the main course of the Heihe River is good and without HM contamination.

However, in the investigated tributaries, the mean concentrations of seven HMs (excluding Arsenic) exceeded the limit recommended by the Chinses surface water and Chinese drinking water standards to varying extents (shown in Table 3). The mean $\mathrm{Cr}$ concentration was 1.29 and 4.29 times higher than the Grade I standard of Chinese surface water in tributary 3 and tributary 4, respectively. Ni exhibited a similar trend, with mean concentrations 1.31 and 8.19 times higher than those of the drinking water standard in tributaries 3 and 4 . This result indicates that water in tributary 4 was severely contaminated with $\mathrm{Cr}$ and $\mathrm{Ni}$. The mean manganese concentration was 1.68 times higher than the drinking water limit value in tributary 6. This result might not reflect the influence of Mn pollution due to the inadequate samples sizes. Moreover, the mean concentration of $\mathrm{Pb}$ was 1.36, 2.81 and 1.28 times higher than the Grade I standard for surface water in tributary 3, tributary 5, and tributary 11, respectively. For $\mathrm{Cu}, \mathrm{Cd}$, and $\mathrm{Zn}$, the most severely contaminated stream was tributary 11 , which was located within the Zhamashi polymetallic belt. Mean concentrations of $\mathrm{Cu}, \mathrm{Cd}$, and $\mathrm{Zn}$ in this tributary were 1.91, 2.49 and 9.7 times higher than the Grade I standards for Chinese surface water respectively. In general, $\mathrm{Cr}$ and $\mathrm{Ni}$ contamination mainly appeared in the upper reaches, whereas $\mathrm{Cu}, \mathrm{Cd}$, and $\mathrm{Zn}$ contamination primarily appeared in lower reaches. However, Pb contamination was found in different reaches of this study area. Except for Arsenic and Mn, other six HMs in the water of the tributaries appeared to be influenced by mining activity, shown in Table 1.

\subsection{Distribution Characteristics of Heavy Metals in Sediment and Water}

Compared with the mean background sediment metal concentrations in the Heihe River basin [10], except for Mn, the remaining seven HMs in sediments show apparent enrichment and considerably greater spatial variability (Figure 2 and Table 4). This result indicates that mining activity has significantly increased the seven HMs in surface sediments. The mean concentrations of these HMs (As, Cr, Ni, Cu, Cd, Pb, and $\mathrm{Zn}$ ) are approximately 2, 1.5, 1.5, 2, 9, 12.5, and 14 times higher than the background mean values given by Bu et al. [10] respectively, while the medians are slightly less than the background mean values, as shown in Table 4. These results show that a small number of 
sediment samples detected extremely high levels of HMs. We preliminarily understand the order of contamination to be $\mathrm{Zn}>\mathrm{Pb}>\mathrm{Cd}>\mathrm{Cu}=\mathrm{As}>\mathrm{Cr}=\mathrm{Ni}>\mathrm{Mn}$.

Table 3. Water quality assessment of heavy metals (HMs) in tributaries and the main course. Mean concentrations of HMs in serval tributaries (units in $\mu \mathrm{g} / \mathrm{L}$ ).

\begin{tabular}{ccccccccccc}
\hline Tributary ID & Mines $^{\mathbf{a}}$ & Samples $^{\mathbf{b}}$ & $\mathbf{A s}$ & $\mathbf{M n}$ & $\mathbf{C r}$ & $\mathbf{N i}$ & $\mathbf{C u}$ & $\mathbf{C d}$ & $\mathbf{P b}$ & $\mathbf{Z n}$ \\
\hline 1 & FX & 2 & 0.00 & 40.02 & 2.18 & 3.03 & 2.56 & 0.10 & 2.92 & 25.70 \\
2 & ZY, JL & 7 & 1.51 & 11.68 & 1.83 & 2.15 & 1.20 & 0.19 & 1.63 & 38.31 \\
3 & RS & 9 & 4.12 & 58.06 & $\underline{12.86}$ & $\underline{26.26}$ & 4.26 & 0.38 & $\underline{13.61}$ & 28.23 \\
4 & HC, SC, YS, QF, XY, DY & 20 & 6.90 & 64.71 & $\underline{42.92}$ & $\underline{163.86}$ & $\underline{11.79}$ & 0.48 & 1.32 & 26.13 \\
5 & BM & 1 & 0.00 & 2.65 & 1.02 & 1.69 & 3.56 & 0.50 & $\underline{28.15}$ & 2.74 \\
6 & LB & 2 & 6.10 & $\underline{167.65}$ & 1.07 & 7.82 & 7.07 & 0.50 & 1.01 & 29.95 \\
7 & QL & 3 & 2.13 & 66.61 & 7.19 & 8.54 & 3.72 & 0.83 & 1.57 & 23.28 \\
8 & JL & 3 & 0.00 & 24.64 & 1.22 & 3.85 & 4.95 & 1.07 & 5.10 & $\underline{55.20}$ \\
10 & ST & 4 & 3.38 & 16.94 & 0.95 & 4.45 & 7.76 & 0.75 & 2.89 & 33.17 \\
11 & WY, XL, XS, GM, XG & 21 & 1.09 & 46.73 & 1.82 & 3.13 & $\underline{19.05}$ & $\underline{2.49}$ & $\underline{12.82}$ & $\underline{489.98}$ \\
12 & GD & 3 & 2.53 & 36.72 & 2.51 & 14.67 & 4.42 & 0.43 & 1.69 & 25.40 \\
& HH & 16 & 4.39 & 24.62 & 3.27 & 5.00 & 1.92 & 0.11 & 0.91 & 22.26 \\
\hline
\end{tabular}

Underlines indicate that the mean concentration of the HM exceeds the corresponding standard, as presented at the beginning of this section. ${ }^{\mathrm{a}}$ all mine locations in Table 3 have been defined in Section 2.1.2 and Table 1. ${ }^{\mathrm{b}}$ Number of water samples which selected for evaluation.

Table 4. Comparisons of HM concentrations in the sediment from the headwaters region of the Heihe River (units in $\mathrm{mg} / \mathrm{kg}$ ).

\begin{tabular}{|c|c|c|c|c|c|}
\hline \multirow{2}{*}{ Metal } & \multicolumn{4}{|c|}{ This Study } & \multirow{2}{*}{$\frac{\text { Background }^{\text {a }}}{\text { Mean }}$} \\
\hline & Min & Max & Median & Mean & \\
\hline As & 1.12 & 728.03 & 19.73 & 42.57 & 21.60 \\
\hline Mn & 293.21 & 2106.08 & 722.64 & 770.65 & 818.84 \\
\hline $\mathrm{Cr}$ & 2.43 & 1148.47 & 45.46 & 88.39 & 57.29 \\
\hline $\mathrm{Ni}$ & 8.96 & 1615.34 & 43.31 & 110.45 & 70.22 \\
\hline $\mathrm{Cu}$ & 6.66 & 2497.69 & 43.98 & 103.28 & 56.38 \\
\hline $\mathrm{Cd}$ & 0.2 & 2349.91 & 2.97 & 27.39 & 2.93 \\
\hline $\mathrm{Pb}$ & 0 & $26,538.82$ & 23.22 & 470.22 & 37.35 \\
\hline $\mathrm{Zn}$ & 31.87 & $210,880.62$ & 128.31 & 2460.93 & 178.68 \\
\hline
\end{tabular}

The water quality results described above reveal different degrees of HMs contamination in several tributaries. However, the leaching of some minerals into steam water and pond water, which was therefore present a relatively high HM concentration, was not considered. In Figure 2, all water samples plotted.

The above water quality assessment shows that there was no arsenic pollution in any of the tributaries or the main course of the Heihe River. However, Figure 2 shows a large range of arsenic concentrations. In addition, the arsenic concentration in both sediment and water exhibited relatively high concentrations at the ore concentration belt of Yushigou and Zhamashi. High concentrations of $\mathrm{Cr}$ and $\mathrm{Ni}$ in sediments and waters were mainly found in the Reshuigou and Yushigou areas (Figures $1 \mathrm{~b}$ and 2), where the Yushigou ophiolite belt is located (shown in Figure S1). These results indicated that the sources of $\mathrm{Cr}$ and Ni might be the Yushigou.

The mean manganese $(\mathrm{Mn})$ concentration for sediments $(770.65 \mathrm{mg} / \mathrm{kg})$ was slightly lower than the background value $(818.84 \mathrm{mg} / \mathrm{kg}$ ) described by Bu et al. [10]. Moreover, the majority of water samples showed a low Mn concentration $(<100 \mu \mathrm{g} / \mathrm{L})$, except for eight mineral leached waters with a high concentration $(>1400 \mu \mathrm{g} / \mathrm{L})$ collected in polymetallic or Mn mines around Zhamashi (Figures $1 \mathrm{~b}$ and 2). The consistent pattern of low Mn both in waters and sediments but high Mn in the waters and sediments around the corresponding mines might suggest that there were no apparent effects related to the distribution of the Mn mines. 
The HM concentrations of $\mathrm{Cu}, \mathrm{Cd}, \mathrm{Pb}$ and $\mathrm{Zn}$ samples were mainly collected in the Chuancigou and Zhamashi areas, which included the polymetallic and lead-zinc deposits. HMs in waters produced a similar spatial distribution pattern, and relatively high values (including the peak values) of the four $\mathrm{HMs}(\mathrm{Cu}, \mathrm{Cd}, \mathrm{Pb}$, and $\mathrm{Zn})$ were found in the Zhamashi polymetallic belt. Based on the above analysis, except for Mn, the spatial distribution of HMs in waters and sediments shows a high degree of consistency and is coincident with the mine areas. The strongly consistent distribution of HMs in waters and sediments reflects a close connection between water and surface sediment. Our sampling sites, such as SC, HC, YS, ZY, DY, and QF, are located near the uppermost sections of tributaries at high elevations, as shown in Figure 1b. In nature, weak weathering is not conducive to the enrichment of heavy metals in surface sediments and water bodies [36]. Thus, mining activity might increase the levels of HMs in sediments by accelerating bedrock weathering [10,37], especially with the open-pit mining method practiced in Yushigou and Chuancigou (Table 1). The above analysis explains the high concentrations of $\mathrm{Cr}, \mathrm{Ni}$, and $\mathrm{As}$ in the Yushigou area. However, the explanation for $\mathrm{Cr}, \mathrm{Ni}$, and $\mathrm{As}$ cannot be applied to analyze the high concentrations of $\mathrm{Cu}, \mathrm{Mn}, \mathrm{Pb}, \mathrm{Zn}$, and $\mathrm{As}$ in Zhamashi because underground mining was the primary practice in Zhamashi.

\subsection{The Interaction of Surface Water, Groundwater, and Mining Waste Leaching Water}

Analyzing the processes of basin runoff aid in understanding the pathway of HM transport. The pattern of $\delta \mathrm{D}$ and $\delta^{18} \mathrm{O}$ in all water bodies were analyzed. The mean isotopic compositions of precipitation at different elevations were adopted as reference values [6,38]. Figure 3 shows the clustering of data for meltwater, precipitation and mineral leached waters. As shown in Figure 3, the locations of $\delta^{18} \mathrm{O}$ versus $\delta \mathrm{D}$ for river water, groundwater, pond water and mineral leached water in the different elevation zones were close to or offset from the local meteoric water line (LMWL) [38], suggesting a relatively shallow depth for the basin hydrological cycle in the headwaters of the Heihe River.

Compared with other waters, meltwaters had lower values of $\delta^{18} \mathrm{O}$ and $\delta \mathrm{D}$ than those found in the other water bodies in the headwaters of the Heihe River. All river water isotope compositions plotted between the cluster of melt water and the cluster of precipitation, meaning that precipitation and glacier meltwater co-supplied the river during August 2013.

Above an elevation of $4000 \mathrm{~m}$, more negative $\delta^{18} \mathrm{O}$ values for river waters were presented, ranging from $-9.54 \%$ to $-8.08 \%$, which suggested that the upper reaches of rivers mainly recharged from glacier melt. However, as elevation decreased, the river water isotope composition gradually approached the LMWL and the average isotopic composition of precipitation. At elevations below $4000 \mathrm{~m}$, relatively positive $\delta^{18} \mathrm{O}$ values ranged from $-7.80 \%$ to $-1.94 \%$, indicating that precipitation is the main water source in middle to lower reaches of this study area.

As the study area is a typical nested watershed model, with the decrease in elevation, the river catchment area gradually increases, and meltwater and precipitation discharge into the Heihe River along the way. The isotopic composition contribution from precipitation to river water increased, as expected. This pattern agrees with previous research results [6,12,39]. Moreover, Gao et al. [12] discovered that the contribution ratio of glacier meltwater to river discharge was quite low in summer due to the relatively small glacier (less than $1 \%$ of the basin area) and high level of precipitation.

Groundwater was primarily recharged from meltwater in the upper reaches, and the ratio of precipitation to meltwater increased as elevation decreased. The $\delta^{18} \mathrm{O}$ and $\delta \mathrm{D}$ values in mineral leached water collected from the abandoned mine pit at XL and the bottom of the ore pile at XS were close to the LMWL [38] and between the values for groundwater and precipitation. This result suggests that the mine leached waters were co-supplied by precipitation and groundwater. The average isotope composition of the pond water was even higher than the mean level in precipitation at elevations of $2900-3000 \mathrm{~m}$. These results indicate that pond water was recharged by precipitation and experienced strong evaporation. 


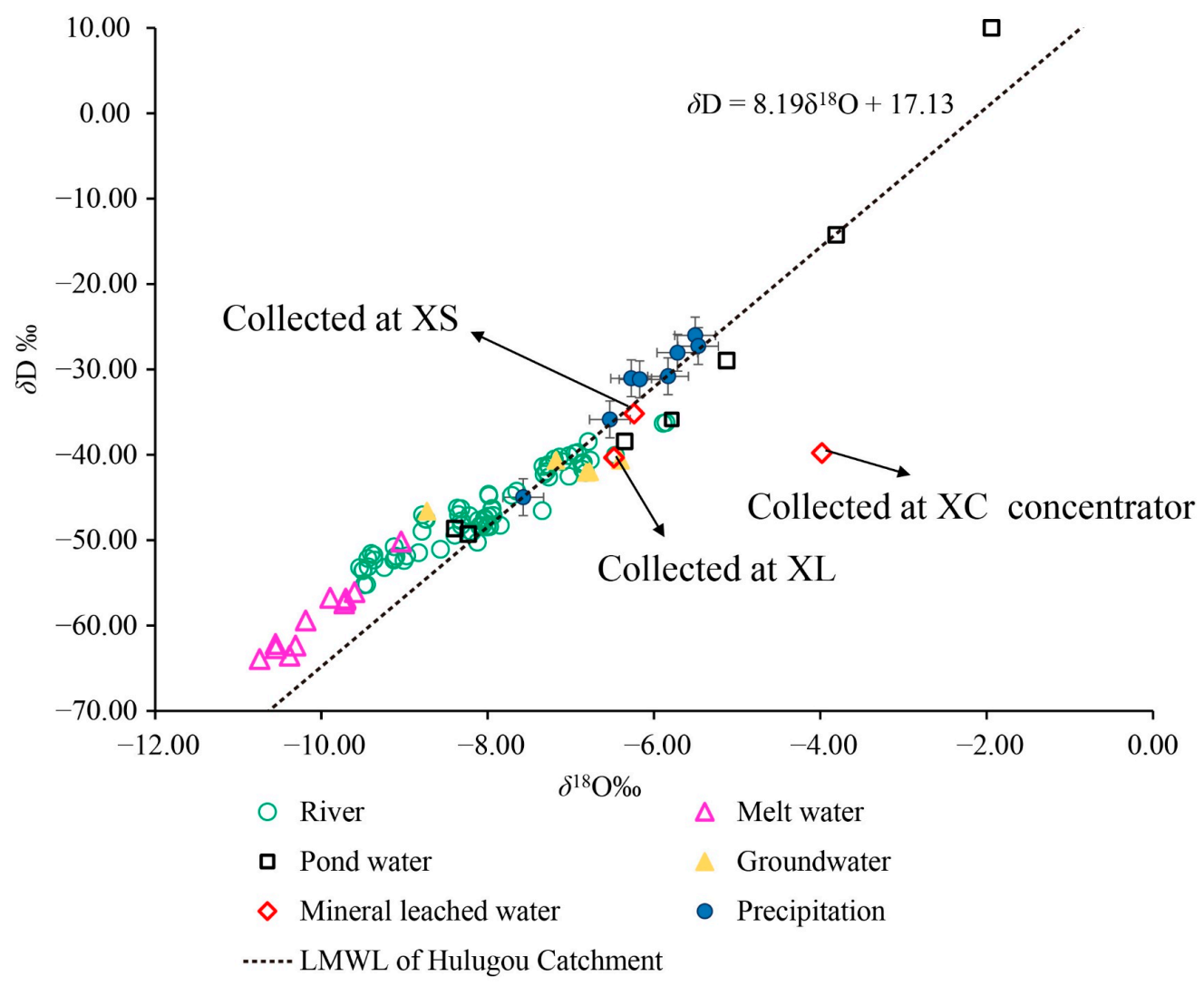

Figure 3. The dual isotope plot of $\delta \mathrm{D}$ vs. $\delta^{18} \mathrm{O}$ for different types of water in 2013 compared to the local meteoric water line for Hulugou Catchment. LMWL represents the local meteoric water line of Tong et al. [38].

The isotopic composition in river water should be particularly close to the cluster of precipitation isotopic compositions when precipitation directly recharges river water. However, mean $\delta^{18} \mathrm{O}$ values increased in the order of meltwater, river water, groundwater, mineral leached water and pond water and were $-10.11 \%,-8.07 \%,-7.45 \%,-6.36 \%$ and $-0.23 \%$, respectively. Compared with pond water, mineral leached water, groundwater, and river water had lower values. This result also supported the conceptual model of the hydrologic process described in $[6,12]$ indicating that precipitation reached the ground through a series of transport flows such as flow through the sediments, surface flow, and base flow entering the river $[6,12,13,40]$. Meltwater also infiltrated into the sediment aquifer and then through groundwater runoff discharge into river runoff $[39,41,42]$.

\subsection{Variability of Heavy Metals Along the Main Course}

The HM concentrations of 16 water samples (HH01-HH16) along the main course, corresponding to tributary (shown in Figure 1) discharge points, were used to further reveal the HM sources and transport routes (Figure 4) due to surface runoff bringing HMs into the main course from tributaries. Based on the isotope analysis results, the river runoff gradually increased along the main course. If the mines had not released the HMs via runoff, all eight HMs would be diluted by freshwater recharged from the precipitation and glacier melt in summer. This process explained why the concentrations of all eight HMs decreased at sampling site HH16. Moreover, as shown in Figure 4, the wave crests were often accompanied by the entry of tributaries affected by mining activities. Seven HMs were measured at sampling site $\mathrm{HH} 01$, not including $\mathrm{Cd}$, indicating that the $\mathrm{HM}$ mineral sources were related to tributary 1 . This area is located on the Zoulang Xibeipor iron belt, and the open-pit mining of the FX limestone might accelerate the weathering of the iron-bearing bedrock. 
$(\mu \mathrm{g} / \mathrm{L})$

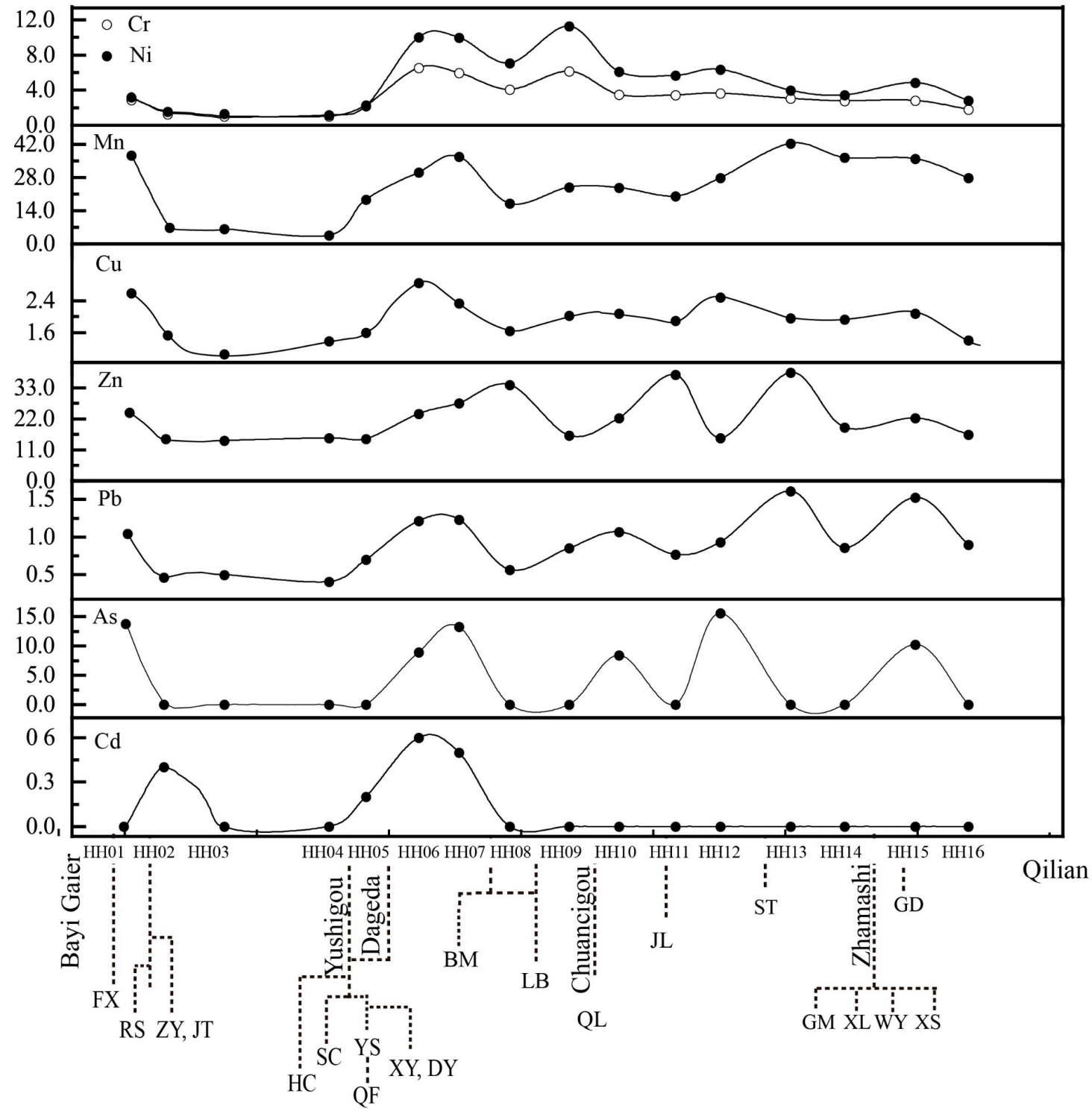

Figure 4. Evolution of HMs along the main courses of the Heihe River, indicating mines discharging into the river. HH01-HH16 indicates the 16 sampling sites in the main course. Different levels of tributaries are also marked (shown Figure S1).

A series of $\mathrm{Cd}$ measurements was conducted at sampling site HH06, where six metals were grouped into three groups due to their similar variations. Group I comprised $\mathrm{Cr}$ and $\mathrm{Ni}$; Group II included $\mathrm{Mn}$ and $\mathrm{Cu}$; and Group III consisted of $\mathrm{Pb}, \mathrm{Zn}$ and As. The variation in $\mathrm{Cr}$ and Ni exhibited the same patterns across the whole range; the two peaks at HH06 and HH09 reflected the exploration of ophiolite-related deposits in Yushigou and Chuancigou, respectively. In Group II, similar behavior of $\mathrm{Mn}$ and $\mathrm{Cu}$ was observed until sampling site $\mathrm{HH} 13$, because the manganese mine at ST significantly increased the Mn concentration at HH13. In Group III, Zn was observed to change more slowly than $\mathrm{Pb}$ after sampling site $\mathrm{HH} 08$; this behavior suggests that extra zinc was discharged into the main course before sampling site HH08. The corresponding tributaries (Figure 4) suggest that BM and QL might be the mineral sources of zinc. For arsenic, a similar fluctuation pattern is shown in Figure 4, but with a more sensitive response to the inputs into tributary 1 , tributary 4 , tributary 6 , and tributary 11 (shown in Figures 1 and 4). 


\subsection{Heavy Metal Provenance Tracing (Factor Analysis)}

Factor analysis (FA) was performed to distinguish the variability among eight heavy metals in sediments and to verify the potential mineral sources in our study area. Table 5 displays the factor loadings with a VARIMAX rotation, as well as the eigenvalues.

From the rotated component matrix for the FA (Table 5), five factors with eigenvalues exceeding one were extracted, accounting for $85.558 \%$ of the total variance. High positive loadings of $\mathrm{Cd}, \mathrm{Cu}, \mathrm{Pb}$, and $\mathrm{Zn}$ in Factor 1 (F1) explained the highest amount of variance at $29.447 \%$. Factor 2 (F2) explained $17.877 \%$ of the total variance, where $\mathrm{Cr}$ and Ni had high loading. Factor 3 (F3) accounted for $14.239 \%$ of the total variance, in which arsenic was positively related to $\mathrm{Cu}$ and $\mathrm{Pb}$ with high loading. Moreover, Facor 4 (F4) explained $13.509 \%$ of the total variance, which was characterized by favorable loadings for TOC and negative loadings on $\mathrm{pH}$. Factor 5 (F5) contributed $9.181 \%$ of the total variance and was characterized by positive loadings for $\mathrm{Mn}$.

$\mathrm{Cu}, \mathrm{Pb}$, and $\mathrm{Zn}$ have high affinities to polymetallic deposits and combinations of $\mathrm{Cu}-\mathrm{Pb}-\mathrm{Zn}$ and $\mathrm{Cu}-\mathrm{Zn}$ are widespread [9]. In addition, $\mathrm{Cd}$ is considered a typical chalcophile element and is often found in $\mathrm{Zn}$ sulfides [24,43]. These metals are commonly found together in various types of ore deposits in this area [44], reflecting an adequate mineral source. Mining activity also plays an important role according to the strong enrichment intensity. Another chalcophile element, arsenic (As) is grouped into F3 with $\mathrm{Cu}$. In F2, $\mathrm{Cr}$ and Ni might originate more from the underlying bedrock weathering but might be slightly affected by mining activity considering their relatively weak enrichment intensities. The elements are supplied by basic and ultrabasic rocks such as peridotite, basalt, and gabbro in the Yushigou and Chuancigou ophiolite sequences [19,20,44]. F4 can be treated as the influence of the acid mine discharge (AMD). There are definite loadings on $\mathrm{Cd}, \mathrm{Cu}, \mathrm{Pb}$ and $\mathrm{Zn}$ in F4, with negative loadings on $\mathrm{Cr}, \mathrm{Mn}$, and $\mathrm{Ni}$. This pattern indicates that AMD transports HMs into the surface sediment. $\mathrm{Mn}$ is always treated as a conservative metal due to its stable physicochemical characteristics [45-47]; these features distinguish it from the other HMs [48].

Table 5. VARIMAX rotated factor loading matrix for sediments. The numbers in bold indicate that the loads are above 0.5 .

\begin{tabular}{cccccc}
\hline Variables & F1 & F2 & F3 & F4 & F5 \\
\hline $\mathrm{Cd}$ & $\mathbf{0 . 9 7 4}$ & 0.033 & 0.064 & 0.131 & 0.021 \\
$\mathrm{Cr}$ & 0.071 & $\mathbf{0 . 9 7 8}$ & 0.034 & -0.072 & -0.005 \\
$\mathrm{Cu}$ & $\mathbf{0 . 6 0 7}$ & -0.063 & $\mathbf{0 . 6 9 3}$ & 0.097 & -0.009 \\
$\mathrm{Mn}$ & -0.060 & 0.023 & -0.117 & -0.064 & $\mathbf{0 . 9 0 1}$ \\
$\mathrm{Ni}$ & -0.042 & $\mathbf{0 . 9 8 4}$ & 0.048 & -0.014 & -0.018 \\
$\mathrm{~Pb}$ & $\mathbf{0 . 8 8 7}$ & -0.013 & $\mathbf{0 . 4 2 5}$ & 0.112 & -0.023 \\
$\mathrm{Zn}$ & $\mathbf{0 . 9 7 5}$ & 0.030 & 0.085 & 0.129 & 0.016 \\
$\mathrm{As}$ & 0.160 & 0.123 & $\mathbf{0 . 8 8 1}$ & 0.012 & -0.063 \\
$\mathrm{pH}$ & -0.035 & 0.034 & -0.279 & $-\mathbf{0 . 8 7 9}$ & -0.096 \\
$\mathrm{TOC}(\mathrm{g} / \mathrm{kg})$ & 0.276 & -0.042 & -0.299 & $\mathbf{0 . 7 3 5}$ & -0.151 \\
EC $(\mu \mathrm{s} / \mathrm{cm})$ & 0.264 & -0.128 & 0.279 & 0.326 & 0.400 \\
\hline Eigenvalues & 3.239 & 1.966 & 1.710 & 1.486 & 1.010 \\
\% of Variance & 29.447 & 17.877 & 15.544 & 13.509 & 9.181 \\
Cumulative \% & 29.447 & 47.323 & 62.867 & 76.376 & 85.558 \\
\hline
\end{tabular}

\subsection{Identifying Hydrogeochemical Processes}

Factor analysis of the 34 variables was applied to reveal the influence of HMs released into water environments. The first six varimax rotated factors were extracted according to the Kaiser criterion (Table 6), accounting for $81.33 \%$ of the total variance. High positive loadings on $\mathrm{As}, \mathrm{Be}, \mathrm{Co}, \mathrm{Sn}, \mathrm{Bi}$, Th, $\mathrm{U}, \mathrm{EC}, \mathrm{F}^{-}, \mathrm{SO}_{4}{ }^{2-}, \mathrm{Fe}, \mathrm{K}$, and $\mathrm{Si}$ in $\mathrm{F} 1$ explained the highest amount of variance at $34.60 \%$, indicating that aluminosilicate weathering was the primary source for these elements [49]. The $\mathrm{pH}$ had a negative association and $\mathrm{SO}_{4}{ }^{2-}$ was positively related to these trace elements, indicating that the " $\mathrm{H}^{+\prime}$ acid 
released during mining activities enhanced the release of those elements. Mining activities accelerated this process, especially in sulfide deposits as commonly reported [43,50,51].

Table 6. VARIMAX rotated factor loading matrix for waters. The numbers in bold indicate that the loads are above 0.5 .

\begin{tabular}{|c|c|c|c|c|c|c|}
\hline Variables & F1 & F2 & F3 & F4 & F5 & F6 \\
\hline As & 0.99 & 0.02 & 0.01 & -0.01 & 0.07 & 0.11 \\
\hline $\mathrm{Cd}$ & 0.40 & 0.05 & 0.01 & 0.01 & 0.89 & 0.02 \\
\hline $\mathrm{Li}$ & 0.21 & 0.82 & 0.11 & 0.16 & 0.11 & 0.07 \\
\hline $\mathrm{Be}$ & 0.97 & 0.06 & 0.01 & 0.07 & 0.13 & 0.13 \\
\hline $\mathrm{Cr}$ & 0.22 & -0.03 & -0.02 & -0.02 & 0.03 & 0.94 \\
\hline Mn & 0.40 & 0.08 & 0.01 & 0.87 & 0.22 & 0.05 \\
\hline Co & 0.96 & 0.08 & 0.01 & 0.06 & 0.15 & 0.21 \\
\hline $\mathrm{Ni}$ & 0.26 & 0.01 & -0.07 & 0.01 & 0.10 & 0.91 \\
\hline $\mathrm{Cu}$ & 0.31 & 0.08 & 0.01 & 0.08 & 0.89 & 0.04 \\
\hline $\mathrm{Zn}$ & -0.04 & 0.12 & 0.00 & 0.04 & 0.96 & -0.03 \\
\hline $\mathrm{Rb}$ & -0.07 & 0.23 & 0.76 & 0.46 & 0.06 & 0.03 \\
\hline Mo & 0.17 & 0.56 & -0.08 & -0.14 & 0.09 & -0.07 \\
\hline Sn & 0.99 & 0.03 & 0.02 & -0.01 & 0.08 & 0.11 \\
\hline Cs & 0.00 & 0.07 & 0.14 & 0.94 & -0.04 & 0.07 \\
\hline $\mathrm{Ba}$ & -0.11 & 0.09 & -0.21 & -0.07 & 0.14 & -0.37 \\
\hline $\mathrm{Pb}$ & 0.07 & 0.20 & -0.07 & -0.09 & 0.16 & 0.02 \\
\hline $\mathrm{Bi}$ & 0.99 & 0.02 & 0.01 & -0.01 & 0.07 & 0.11 \\
\hline Th & 0.99 & 0.02 & 0.01 & 0.02 & 0.07 & 0.11 \\
\hline $\mathrm{U}$ & 0.91 & 0.27 & -0.01 & 0.04 & 0.04 & 0.06 \\
\hline $\mathrm{EC}$ & 0.67 & 0.26 & 0.62 & 0.22 & 0.17 & 0.04 \\
\hline $\mathrm{pH}$ & -0.70 & -0.42 & 0.13 & -0.16 & -0.33 & -0.03 \\
\hline $\mathrm{CO}_{3}{ }^{2-}$ & -0.05 & -0.16 & 0.75 & -0.15 & -0.12 & -0.06 \\
\hline $\mathrm{HCO}_{3}{ }^{-}$ & -0.12 & 0.58 & -0.10 & -0.13 & -0.24 & -0.32 \\
\hline $\mathrm{F}^{-}$ & 0.61 & 0.50 & -0.01 & 0.27 & 0.26 & 0.01 \\
\hline $\mathrm{Cl}^{-}$ & -0.02 & -0.01 & 0.96 & 0.03 & -0.01 & 0.07 \\
\hline $\mathrm{NO}_{3}{ }^{-}$ & 0.00 & 0.05 & 0.02 & 0.95 & -0.03 & -0.02 \\
\hline $\mathrm{SO}_{4}{ }^{2-}$ & 0.96 & 0.13 & 0.04 & 0.10 & 0.16 & 0.08 \\
\hline $\mathrm{Ca}$ & 0.38 & 0.40 & 0.09 & 0.33 & 0.30 & -0.16 \\
\hline $\mathrm{Fe}$ & 0.99 & 0.03 & 0.01 & -0.01 & 0.07 & 0.11 \\
\hline $\mathrm{K}$ & 0.46 & 0.23 & 0.17 & 0.17 & 0.08 & -0.06 \\
\hline $\mathrm{Mg}$ & 0.11 & 0.13 & 0.94 & 0.09 & 0.06 & 0.06 \\
\hline $\mathrm{Na}$ & 0.06 & 0.81 & 0.24 & 0.36 & -0.04 & 0.03 \\
\hline $\mathrm{Si}$ & 0.98 & 0.07 & -0.01 & 0.02 & 0.08 & 0.15 \\
\hline $\mathrm{Sr}^{2+}$ & 0.07 & 0.86 & 0.09 & 0.15 & 0.10 & 0.00 \\
\hline Eigenvalues & 11.77 & 3.70 & 3.55 & 3.32 & 3.14 & 2.18 \\
\hline$\%$ of Variance & 34.60 & 10.88 & 10.43 & 9.77 & 9.24 & 6.41 \\
\hline Cumulative \% & 34.60 & 45.48 & 55.91 & 65.68 & 74.92 & 81.33 \\
\hline
\end{tabular}

Extraction method: Principal component analysis. Rotation method: Varimax with Kaiser normalization.

F2 accounted for $10.88 \%$ of the variance, where $\mathrm{Li}, \mathrm{Mo}, \mathrm{HCO}_{3}{ }^{-}, \mathrm{Ca}, \mathrm{Na}$, and $\mathrm{Sr}^{2+}$ had positive associations; $\mathrm{pH}$ was also had a negative loading $(-0.42)$ in this factor, reflecting the dissolution of post-Devonian carbonate or intermediate volcanic rocks. F3 accounted for 10.43\% of the total variance, with definite loadings on $\mathrm{EC}, \mathrm{Rb}, \mathrm{CO}_{3}{ }^{2-}, \mathrm{Cl}$, and $\mathrm{Mg}$. This element combination indicated the dissolution of evaporites or rocks bearing layered silicates (e.g., hydromica, chlorite, glauconite) [20,44].

F4 was characterized by positive loadings on $\mathrm{Mn}, \mathrm{Cs}$, and $\mathrm{NO}_{3}{ }^{-}$, which explained $9.77 \%$ of the total variance and suggested artificial contamination [24,36]. Positive $\mathrm{NO}_{3}{ }^{-}$is often related to the presence of organic matter or nutrients, reflecting the influence of anthropogenic activities such as agriculture and grazing. In our study area, grazing might more important than agriculture, as the alpine meadow pastures are widespread, whereas the total area of several farmlands near HH05 is 
so small (less than 4\%), shown in Figure S2. Mn and Cs have robust biological affinities. Bacteria, terrestrial plants, and crops are enriched in these two elements [24].

F5 was responsible for $9.24 \%$ of the total variance and had strong positive loadings on $\mathrm{Cu}(0.843)$ and $\mathrm{Zn}$ (0.933). $\mathrm{Pb}$ also showed relatively weak affiliation with these two elements with a value of 0.385 . This association could be attributed to $\mathrm{Cu}-\mathrm{Zn}$ and $\mathrm{Cu}-\mathrm{Pb}-\mathrm{Zn}$ mining activity.

F6 accounted for $6.41 \%$ of the total variance, and $\mathrm{Ni}$ and $\mathrm{Cr}$ were strongly associated with high loadings of 0.94 and 0.91 , respectively. Mixed sources originated from both natural and anthropogenic inputs while $\mathrm{Cr}$ and $\mathrm{Ni}$ were homologous and sourced from the weathering of basic gabbro and serpentine in ophiolites [24,36,43].

Based on the preceding water and sediment FA, we can recognize that mineral weathering and dissolution dominate the main hydro-chemical composition. HMs in water environments also arise from anthropogenic inputs such as mining, agriculture, and grazing. In general, F1, F2, and F3 mostly represent rock/mineral weathering, although they may be affected by mining activity, while F4, F5, and F6 explain the anthropogenic influences or inputs. Among these factors, mining might have a significant contribution, as explained by F5 and F6 (shown in Figure 5).

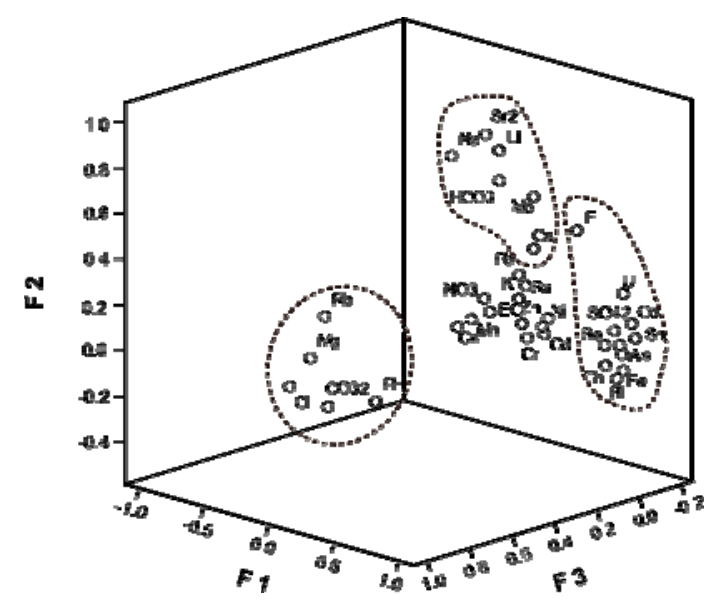

(a)

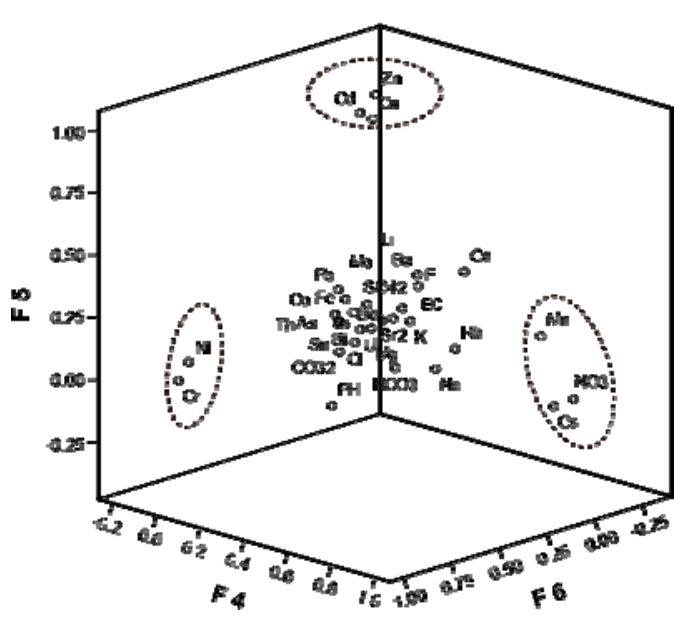

(b)

Figure 5. 3-D plots of the FA loadings. (a) Weathering factors described by F1, F2, and F3. (b) Anthropogenic influences or inputs explained by F4, F5, and F6.

\subsection{Impact of Mining Activity}

To further understand the impact of mining, the mine investigation information was combined with the above analysis of HM mineral sources, water sources, and runoff paths. In both sediment and water, there are two ways that mining impacts the hydro-chemical conditions: enhanced mineral weathering and AMD. In the upper reaches of our study area, meltwater is a primary water source, and open-pit mining was the primary mining practice at several mines (RS, HC, XY, SC, YS, QF, and DY), which are mainly active in the Ophiolite Complex (shown in Table 1 and Figure S1). Open-pit mining activity apparent increases the contact between ore and oxygen by crushing ores and results in changes to the original redox state of the ore. When Meltwater though the mining area surface sediment, $\mathrm{HMs}$ of $\mathrm{Cr}, \mathrm{Ni}$, and Arsenic were carried to runoff. Considering the result of FA, AMD might also infiltrate into the sediment aquifer and promote HM dissolution from sediment minerals by providing " $\mathrm{H}^{+\prime}$ [52-54].

A similar process also occurred at site near underground mining. Underground mining introduces oxygen to the deep geological environment and brings minerals to the surface to be deposited in spoil tips $[45,51,55]$. HMs in surface sediment can also be enhanced by mineral weathering. However, the weathering rate was far slower than that in open-pit mining because open-pit mining provides a larger contact area between the ore and the air. Table 1 shows that underground mining mainly is 
practiced at the mining sites in middle and lower reaches of this study area where precipitation is the main water source, and the rate of weathering is faster than that in upper reaches at elevation above 4000 (m.s.l).

Therefore, high level of HMs in the Zhamashi sites such as GM, WY, XL, and XS might be attributed to a comprehensive process. Precipitation leaches HMs from mineral spoil tips and surface sediment and transport these elements via runoff. AMD might not only enhance weathering and dissolution by reducing sediment $\mathrm{pH}$, but also carry HMs into runoff directly. For the polymetallic mines at high elevations such as JT, meltwater is the primary source. Meltwater, as a primary carrier of HMs, directly pours into the river through underground seepage and surface runoff. HMs are mainly carried by AMD.

\section{Conclusions}

This research investigated the spatial distribution of heavy metals (HMs) and assessed water quality in the headwater region of the Heihe River, which has a fragile ecological environment. Factor analysis (FA) and the isotope relationships of $\delta \mathrm{D}$ and $\delta^{18} \mathrm{O}$ were used to identify the mineral sources and water sources. On this basis, the pathways of HMs were also recognized.

The results of water quality analysis suggested that tributaries were affected by mining activity and that excessive elements in surface waters had direct relationships with local mining areas. The ores varieties in the local mining areas were often composed of elements exceeding water quality standards. The consistent distribution of HMs in waters and sediments reflected a close connection between water and surface sediments. The different sources were distinguished based on FA in waters and sediments. HMs in sediments were inherited from the underlying parent bedrock. Mineral weathering and dissolution dominated the main hydro-chemical composition. HMs in water environments are mainly sourced from anthropogenic activities such as mining, agriculture, and grazing. $\mathrm{Cr}, \mathrm{Ni}, \mathrm{Cd}$, $\mathrm{Cu}, \mathrm{Zn}, \mathrm{As}$ and $\mathrm{Pb}$ appeared to be influenced more by mining activity. $\mathrm{Cd}, \mathrm{Cu}, \mathrm{Zn}, \mathrm{As}$ and $\mathrm{Pb}$ were sourced from the mining of metal sulfide deposits such as polymetallic, lead-zinc, manganese and iron mines. $\mathrm{Cr}$ and $\mathrm{Ni}$ were homologous and were sourced from the mining activity in basic gabbro and serpentine of the ophiolites complex. Mn appeared to be influenced primarily by artificial activities such as agriculture and grazing.

Combining the mine investigation information with the above results on the water quality mineral sources, water sources, and runoff paths revealed, two main mining influences depending on different mining methods. For open-pit mining, mining promoted the release of HMs via enhanced weathering. For underground mining, HMs might have contributed more AMD at high elevations. As the elevation decreased, precipitation increased; A series of complex hydrological factor significantly affected leaching and runoff.

Supplementary Materials: The following are available online at http:/ /www.mdpi.com/1660-4601/15/9/1987/s1, Figure S1: Geological map of the headwater regions of Heihe River Basin; Figure S2: The Land Use Coverage of the headwater region of the Heihe River Basin.

Author Contributions: Data curation: J.B.; Formal analysis: Y.L.; Investigation: W.W. and J.B.; Methodology: X.L.; Project administration: Z.S. and A.Z.; Resources: R.M.; Supervision: R.M.; Writing of the original draft: W.W.

Funding: This research was financially supported by the National Key Research and Development Program of China (2017YFC0406105) and the National Natural Science Foundation of China (NSFC-41772270).

Conflicts of Interest: The authors declare no conflict of interest.

\section{References}

1. Förstner, U.; Wittmann, G. Metal Pollution in the Aquatic Environment; Springer: Berlin, Germany, 1983; ISBN 9783540128564.

2. Meng, Q.; Zhang, J.; Zhang, Z.; Wu, T. Geochemistry of dissolved trace elements and heavy metals in the Dan River Drainage (China): Distribution, sources, and water quality assessment. Environ. Sci. Pollut. Res. 2016, 23, 8091-8103. [CrossRef] [PubMed] 
3. Shi, X.; Chen, L.; Wang, J. Multivariate analysis of heavy metal pollution in street dusts of Xianyang city, NW China. Environ. Earth Sci. 2013, 69, 1973-1979. [CrossRef]

4. Kumar, M.; Ramanatahn, A.L.; Tripathi, R.; Farswan, S.; Kumar, D.; Bhattacharya, P. A study of trace element contamination using multivariate statistical techniques and health risk assessment in groundwater of Chhaprola Industrial Area, Gautam Buddha Nagar, Uttar Pradesh, India. Chemosphere 2017, 166, 135-145. [CrossRef] [PubMed]

5. Zhou, J.-M.; Dang, Z.; Cai, M.-F.; Liu, C.-Q. Soil Heavy Metal Pollution Around the Dabaoshan Mine, Guangdong Province, China. Pedosphere 2007, 17, 588-594. [CrossRef]

6. Zhao, L.J.; Yin, L.; Xiao, H.L.; Cheng, G.D.; Zhou, M.X.; Yang, Y.G.; Li, C.Z.; Zhou, J. Isotopic evidence for the moisture origin and composition of surface runoff in the headwaters of the Heihe River basin. Chin. Sci. Bull. 2011, 56, 406-415. [CrossRef]

7. Cheng, G.; Li, X.; Zhao, W.; Xu, Z.; Feng, Q.; Xiao, S.; Xiao, H. Integrated study of the water-ecosystem-economy in the Heihe River Basin. Natl. Sci. Rev. 2014, 1, 413-428. [CrossRef]

8. Zhong, Z. The Chinese western development initiative: New opportunities for mineral investment. Resour. Policy 2002, 28, 117-131. [CrossRef]

9. Xiao, C.; Zou, X.; Jia, Q.; Yang, Z. Present situation of the mineral resource in Qilian metallogenic belt and thinking. Northwest. Geol. 2003, 36, 38-49.

10. Bu, J.; Sun, Z.; Zhou, A.; Xu, Y.; Ma, R.; Wei, W.; Liu, M. Heavy metals in surface soils in the upper reaches of the Heihe River, northeastern Tibetan Plateau, China. Int. J. Environ. Res. Public Health 2016, 13, 247. [CrossRef] [PubMed]

11. Yan China Punishes Officials Over Environmental Violations in Qilian Mountains. Available online: http: / / www.xinhuanet.com/english/2017-07/20/c_136459844.htm (accessed on 20 July 2018).

12. Gao, B.; Qin, Y.; Wang, Y.; Yang, D.; Zheng, Y. Modeling ecohydrological processes and spatial patterns in the upper Heihe basin in China. Forests 2016, 7, 10. [CrossRef]

13. Ma, R.; Sun, Z.; Hu, Y.; Chang, Q.; Wang, S.; Xing, W.; Ge, M. Hydrological connectivity from glaciers to rivers in the Qinghai-Tibet Plateau: Roles of suprapermafrost and subpermafrost groundwater. Hydrol. Earth Syst. Sci. 2017, 21, 4803-4823. [CrossRef]

14. Yang, Q.; Xiao, H.; Zhao, L.; Yang, Y.; Li, C.; Zhao, L.; Yin, L. Hydrological and isotopic characterization of river water, groundwater, and groundwater recharge in the Heihe River basin, northwestern China. Hydrol. Process. 2011, 25, 1271-1283. [CrossRef]

15. Yang, Y.; Xiao, H.; Wei, Y.; Zhao, L.; Zou, S.; Yin, Z.; Yang, Q. Hydrologic processes in the different landscape zones of Mafengou River basin in the alpine cold region during the melting period. J. Hydrol. 2011, 409, 149-156. [CrossRef]

16. Yang, Y.G.; Xiao, H.L.; Zou, S.B.; Zhao, L.J.; Zhou, M.X.; Hou, L.G.; Wang, F. Hydrochemical and hydrological processes in the different landscape zones of alpine cold region in China. Environ. Earth Sci. 2012, 65, 609-620. [CrossRef]

17. Li, Z.; Qi, F.; Li, J.; Pan, Y.; Wang, T.; Li, L.; Xiaoyan, G.; Yan, G.; Bing, J.; Rui, G. Environmental significance and hydrochemical processes at a cold alpine basin in the Qilian Mountains. Environ. Earth Sci. 2015, 73, 4043-4052. [CrossRef]

18. Li, X.; Cheng, G.; Ge, Y.; Li, H.; Han, F.; Hu, X.; Tian, W.; Tian, Y.; Pan, X.; Nian, Y.; et al. Hydrological Cycle in the Heihe River Basin and Its Implication for Water Resource Management in Endorheic Basins. J. Geophys. Res. Atmos. 2018, 123, 890-914. [CrossRef]

19. Xia, X.H.; Song, S.G. Forming age and tectono-petrogenises of the Jiugequan ophiolite in the North Qilian Mountain, NW China. Chin. Sci. Bull. 2010, 55, 1899-1907. [CrossRef]

20. Song, S.; Niu, Y.; Su, L.; Xia, X. Tectonics of the North Qilian orogen, NW China. Gondwana Res. 2013, 23, 1378-1401. [CrossRef]

21. Baranova, A.; Schickhoff, U.; Wang, S.; Jin, M. Mountain pastures of Qilian Shan: Plant communities, grazing impact and degradation status (Gansu province, NW China). Geophys. Res. Abstr. 2016, 21-35. [CrossRef]

22. Xia, L.; Xia, Z.; Xu, X. Early Palaeozoic Mid-Ocean Rudge-Ocean Island and Back-Arc Basin Volcanism in the North Qilian Mountains. Acta Geol. Sin. 1998, 72, 301-312.

23. Yi, Y.; Dong, X.; Du, Z.; Yuan, K.; Cao, S. Analysis of metallogenic conditions of metamorphic sedimentary iron ore deposit in the upper stream of the Black River along Qilian mountain range. Miner. Explor. 2015, $6,397-404$. 
24. Bowen, H.J.M. Environmental Chemistry of the Elements; Academic Press: New York, NY, USA, 1979.

25. Xiao, Y.; Niu, Y.; Wang, K.L.; Lee, D.C.; Iizuka, Y. Geochemical behaviours of chemical elements during subduction-zone metamorphism and geodynamic significance. Int. Geol. Rev. 2016, 58, 1253-1277. [CrossRef]

26. Gran, G.; Dahlenborg, H.; Laurell, S.; Rottenberg, M. Determination of the Equivalent Point in Potentiometric Titrations. Acta Chem. Scand. 1950, 4, 559-577. [CrossRef]

27. Sun, Z.; Long, X.; Ma, R. Water uptake by saltcedar (Tamarix ramosissima) in a desert riparian forest: Responses to intra-annual water table fluctuation. Hydrol. Process. 2016, 30, 1388-1402. [CrossRef]

28. Goyer, R.; Mehlman, M. Toxicology of Trace Elements; Hemisphere Publishing Corporation: Dubrovnik, Croatia, 1977.

29. Sheng, J.; Weather, B.; Office, M.; Wang, X.; Gong, P.; Tian, L. Heavy metals of the Tibetan top soils. Environ. Sci. Pollut. Res. 2012, 19, 3362-3370. [CrossRef] [PubMed]

30. Zhang, J.; Wang, Y.; Liu, J.; Liu, Q.; Zhou, Q. Multivariate and geostatistical analyses of the sources and spatial distribution of heavy metals in agricultural soil in Gongzhuling, Northeast China. J. Soils Sediments 2016, 16, 634-644. [CrossRef]

31. Doabi, S.A.; Afyuni, M.; Karami, M. Multivariate statistical analysis of heavy metals contamination in atmospheric dust of Kermanshah province, western Iran, during the spring and summer 2013. J. Geochem. Explor. 2017, 180, 61-70. [CrossRef]

32. Liu, H.; Zhang, Y.; Zhou, X.; You, X.; Shi, Y.; Xu, J. Source identification and spatial distribution of heavy metals in tobacco-growing soils in Shandong province of China with multivariate and geostatistical analysis. Environ. Sci. Pollut. Res. 2017, 24, 5964-5975. [CrossRef] [PubMed]

33. Wang, J.; Liu, G.; Liu, H.; Lam, P.K.S. Multivariate statistical evaluation of dissolved trace elements and a water quality assessment in the middle reaches of Huaihe River, Anhui, China. Sci. Total Environ. 2017, 583, 421-431. [CrossRef] [PubMed]

34. State Environmental Protection Administration of China (SEPA); General Administration of Quality Supervision (AQSIQ). Chinese National Standards GB 3838-2002: Environmental Quality Standards for Surface Water; China Water Risk: Hongkong, China, 2002.

35. Ministry of Health of the People's Republic of China (MOH); Standardization Administration of China (SAC). Chinese National Standards GB 3838-2002: Sanitary Standards for Drinking Water Quality; China Water Risk: Hongkong, China, 2006.

36. Pfeifer, H.R.; Derron, M.H.; Rey, D.; Schlegel, C.; Atteia, O.; Piazza, R.D.; Dubois, J.P.; Mandia, Y. Chapter 2 Natural trace element input to the soil-sediment-water-plant system: Examples of background and contaminated situations in Switzerland, Eastern France and Northern Italy. Trace Met. Environ. 2000, 4, 33-86. [CrossRef]

37. Alloway, B.J. Sources of Heavy Metals and Metalloids in Soils. In Heavy Metals in Soils: Trace Metals and Metalloids in Soils and their Bioavailability; Alloway, B.J., Ed.; Springer: Dordrecht, The Netherlands, 2013; pp. 11-50, ISBN 978-94-007-4470-7.

38. Tong, J.; Zhou, M.; Sun, Z.; Chang, Q.; Li, J. Water vapor sources precipitation in the upper reaches of heihe river: Evidence from stable water isotopes and air mass trajectory model. J. Arid Land Resour. Environ. 2013. [CrossRef]

39. Wang, N.L.; Zhang, S.B.; He, J.Q.; Pu, J.C.; Wu, X.B.; Jiang, X. Tracing the major source area of the mountainous runoff generation of the Heihe River in northwest China using stable isotope technique. Chin. Sci. Bull. 2009, 54, 2751-2757. [CrossRef]

40. Yang, Y.; Xiao, H.; Wei, Y.; Zhao, L.; Zou, S.; Yang, Q.; Yin, Z. Hydrological processes in the different landscape zones of alpine cold regions in the wet season, combining isotopic and hydrochemical tracers. Hydrol. Process. 2012, 26, 1457-1466. [CrossRef]

41. Zhang, Y.H.; Song, X.F.; Wu, Y.Q. Use of oxygen-18 isotope to quantify flows in the upriver and middle reaches of the Heihe River, northwestern china. Environ. Geol. 2009, 58, 645-653. [CrossRef]

42. Chang, Q.; Ma, R.; Sun, Z.; Zhou, A.; Hu, Y.; Liu, Y. Using isotopic and geochemical tracers to determine the contribution of glacier-snow meltwater to streamflow in a partly glacierized alpine-gorge catchment in northeastern Qinghai-Tibet Plateau. J. Geophys. Res. Atmos. 2018. [CrossRef]

43. Förstner, U.; Wittmann, G.T.W. Metal Pollution in the Aquatic Environment; Springer: Berlin/Heidelberg, Germany, 1981; ISBN 978-3-540-12856-4. 
44. Zhang, X.P.; Deng, W.; Yang, X.M. The background concentrations of 13 soil trace elements and their relationships to parent materials and vegetation in Xizang (Tibet), China. J. Asian Earth Sci. 2002, 21, 167-174. [CrossRef]

45. Li, Z.; Ma, Z.; van der Kuijp, T.J.; Yuan, Z.; Huang, L. A review of soil heavy metal pollution from mines in China: Pollution and health risk assessment. Sci. Total Environ. 2014, 468-469, 843-853. [CrossRef] [PubMed]

46. Wang, Y. Nanogeochemistry: Nanostructures, emergent properties and their control on geochemical reactions and mass transfers. Chem. Geol. 2014, 378-379, 1-23. [CrossRef]

47. Jin, Z.; You, C.F.; Yu, T.L.; Wang, B.S. Sources and flux of trace elements in river water collected from the Lake Qinghai catchment, NE Tibetan Plateau. Appl. Geochem. 2010, 25, 1536-1546. [CrossRef]

48. Chessa, G.; Calaresu, G.; Ledda, G.; Testa, M.C.; Orrù, A. Chapter 18 Lead, zinc and cadmium in biological tissues of sheep bred in a polluted area. In Trace Metals in the Environment; Elsevier: Amsterdam, The Netherlands, 2000; Volume 4, pp. 479-483, ISBN 0927-5215.

49. Sarmiento, A.M.; Nieto, J.M.; Olías, M.; Cánovas, C.R. Hydrochemical characteristics and seasonal influence on the pollution by acid mine drainage in the Odiel river Basin (SW Spain). Appl. Geochem. 2009, 24, 697-714. [CrossRef]

50. Waseem, A.; Arshad, J.; Iqbal, F.; Sajjad, A.; Mehmood, Z.; Murtaza, G. Pollution Status of Pakistan: A Retrospective Review on Heavy Metal Contamination of Water, Soil, and Vegetables. Biomed. Res. Int. 2014, 2014. [CrossRef] [PubMed]

51. Banks, D.; Younger, P.L.; Arnesen, R.T.; Iversen, E.R.; Banks, S.B. Mine-water chemistry: The good, the bad and the ugly. Environ. Geol. 1997, 32, 157-174. [CrossRef]

52. Lee, P.K.; Baillif, P.; Touray, J.C. Geochemical behaviour and relative mobility of metals (Mn, $\mathrm{Cd}, \mathrm{Zn} \mathrm{and} \mathrm{Pb}$ ) in recent sediments of a retention pond along the A-71 motorway in Sologne, France. Environ. Geol. 1997, 32, 142-152. [CrossRef]

53. Khan, R.; Israili, S.H.; Ahmad, H.; Mohan, A. Heavy Metal Pollution Assessment in Surface Water Bodies and its Suitability for Irrigation around the Neyevli Lignite Mines and Associated Industrial Complex, Tamil Nadu, India. Mine Water Environ. 2005, 24, 155-161. [CrossRef]

54. Huang, X.; Sillanpää, M.; Gjessing, E.T.; Peräniemi, S.; Vogt, R.D. Environmental impact of mining activities on the surface water quality in Tibet: Gyama valley. Sci. Total Environ. 2010, 408, 4177-4184. [CrossRef] [PubMed]

55. Wiggering, H. Sulfide oxidation-An environmental problem within colliery spoil dumps. Environ. Geol. 1993, 22, 99-105. [CrossRef] 